\title{
FACTORS AFFECTING MEDICATION ADHERENCE AMONGST DIABETIC PATIENTS IN INDIA: A CROSS-SECTIONAL STUDY
}

\author{
Vishavjot Aulakh ${ }^{1}$, Chahat Garg ${ }^{1}$, Raminder Kaur ${ }^{1}$, Sourabh Kosey ${ }^{1}$, and Amit Sharma ${ }^{1}$ \\ ${ }^{1}$ ISF College of Pharmacy
}

May 5, 2021

\begin{abstract}
Background: Diabetes is a chronic condition that requires lifelong treatment with anti-diabetic medications to achieve optimum blood sugar level and to prevent complications associated with it but medication non-adherence becomes a major barrier in attaining good glycemic control. Aim: The study was designed to determine the adherence rate to anti-diabetic medications and factors associated with medication non-adherence amongst diabetic patients in Punjab. Materials \& Methods: A crosssectional study was carried out for 3 months on 138 diabetic patients who were using at least one hypoglycemic agent or were on insulin therapy. Hill-Bone Medication Adherence Scale (HB-MAS) - a 9 item questionnaire was used to measure adherence rate. Results: Medication adherence in the study population was above average. $89(64.5 \%)$ had high adherence followed by $41(29.7 \%)$ having moderate and $8(5.8 \%)$ having low adherence. Factors associated with medication non-adherence were age group 18-30 years, male, unmarried, and had a family monthly income $<$ Rs 5000. Conclusion: The factors which affect medication adherence need to be evaluated at the constant interval for an individual patient. Patients must be educated about the disease and the benefits of adhering to their treatment regimen, which eventually improves the quality of life.
\end{abstract}

\section{Hosted file}

research article.pdf available at https://authorea.com/users/412039/articles/520872-factorsaffecting-medication-adherence-amongst-diabetic-patients-in-india-a-cross-sectionalstudy

\section{Hosted file}

tables.pdf available at https://authorea.com/users/412039/articles/520872-factors-affectingmedication-adherence-amongst-diabetic-patients-in-india-a-cross-sectional-study

\section{Hosted file}

Figures for research article.pdf available at https://authorea.com/users/412039/articles/ 520872-factors-affecting-medication-adherence-amongst-diabetic-patients-in-india-across-sectional-study 